\title{
Plasmid-determined Tetracycline Resistance in Streptococcus faecalis: Tandemly Repeated Resistance Determinants in Amplified Forms of pAM $\alpha 1$ DNA
}

\author{
Yoshiniko Yagi and Don B. Clewell \\ Departments of Microbiology and Oral Biology \\ Schools of Medicine and Dentistry \\ and the Dental Research Institute \\ The University of Michigan \\ Ann Arbor, Mich. 48104, U.S.A.
}

(Received 5 August 1975, and in revised form 30 November 1975)

\begin{abstract}
We recently reported that the six-megadalton plasmid pAM $\alpha \mathrm{l}$ (one of two plasmids in Streptococcus faecalis strain DS-5C1) undergoes a gene amplification as a result of extended growth (many generations) of cells in the presence of a subinhibitory concentration of tetracycline. In this communication we present a detailed analysis of this phenomenon using the newly constructed $S$. faecalis strain DT.11, a strain dovoid of plasmid DNA other than pAM $\alpha$ l. It was found that during growth of strain DT-1I in the presence of tetracycline a gradual increase in plasmid size was observed, and this could be correlated with an increase in the level of tetracycline resistance. On the basis of analyses using sucrose density-gradient sedimentation, electron microscopy and the restriction endonuclease EcoRI, it was clearly established that the enlarged DNA contained repeated units of a 2.65 megadalton segment containing the tetracycline resistance determinant. This value $(2 \cdot 65$ megadaltons) also corresponds to the amount of DNA deleted from the plasmid in easily obtainable tetracycline sensitive variants. EcoRI digestion of the amplified DNA structures generated three fragments designated $\alpha_{1}, \alpha_{2}$ and $\alpha_{3}$ with molecular weights of $4 \cdot 20 \times 10^{6}$, $1.75 \times 10^{6}$ and $0.90 \times 10^{6}$, respectively. Unamplified $\mathrm{pAM} \alpha \mathrm{l}$ was cleaved in only two places by the enzyme, while the plasmid of tetracycline sensitive variants (i.e. DNA missing the $\mathbf{2 . 6 5}$ megadalton sequence on which the tetracycline resistance determinant resides) is totally insensitive. In the case of amplified molecules the relative amount of the $\alpha_{2}$ fragment with respect to the $\alpha_{1}$ fragment is much higher than for normal pAM $\alpha$ l. The data indicate that the $\alpha_{2}$ fragment contains the tetracycline resistance determinant; and in the amplified state the addi. tional copies are arranged in tandem connected together by the $\alpha_{3}$ fragment(s). The dater support models which we proposed previously with regard to the mechanism of amplification.

It was also observed that in the amplified state the total amount of closed circular plasmid DNA rolativo to chromosomal DNA was found to be similar to that for the case of unamplified DNA, indicating that when the molecules are larger there are fewer of them.
\end{abstract}

\section{Introduction}

Recent reports from our laboratory have dealt with the structure, function and maintenance of plasmids in the genus Streptococcus (Dunny et al., 1973; Clewell et al., 1974,1975; Clewell \& Franke, 1974; Yagi et al., 1975; Dunny \& Clewell, 1975). A 
hemolytic, drug-resistant clinical isolate designated DS-5 has been shown to harbor three plasmids designated now as $\mathrm{pAM} \alpha \mathrm{l}, \mathrm{pAM} \beta 1$ and $\mathrm{pAM} \gamma \mathrm{l}$ (formerly called $\alpha, \beta$ and $\gamma$ ) with molecular masses of 6,17 and 35 megadaltons, respectively (Clewell et al., 1974). Tetracycline resistance is determined by $\mathrm{pAM} \alpha 1$, whereas $\mathrm{pAM} \beta 1$ confers resistance to erythromycin, lincomycin and vernamycin $\mathrm{B}_{\alpha}$. Hemolysin production as well as two bacteriocin activities (Bac I and Bac II) have been shown to be determined by pAM $\gamma 1$ (Dunny \& Clewell, 1975). The latter plasmid is also transmissible, and is capable of mobilizing the non-transmissible pAM $\alpha \mathbf{l}$ (Dunny \& Clewell, 1975).

In a recent communication we reported on an apparent gene amplification phenomenon that occurs with regard to pAM $\alpha$ l (Clewell et al., 1975). It was found that when Streptococcus faecalis strain DS-5C1 (an erythromycin-sensitive derivative of DS-5 devoid of pAM $\beta 1$ ) is grown in the presence of a sub-inhibitory concentration of tetracycline for an extended period of time (50 to 60 generations), two apparently related phenomena occurred. First, the cells developed a higher level of resistance to the drug; and second, pAM $\alpha$ l was found to increase in size to a molecular weight (somewhat heterogeneous) on the order of 15 to 23 million. When the cells were

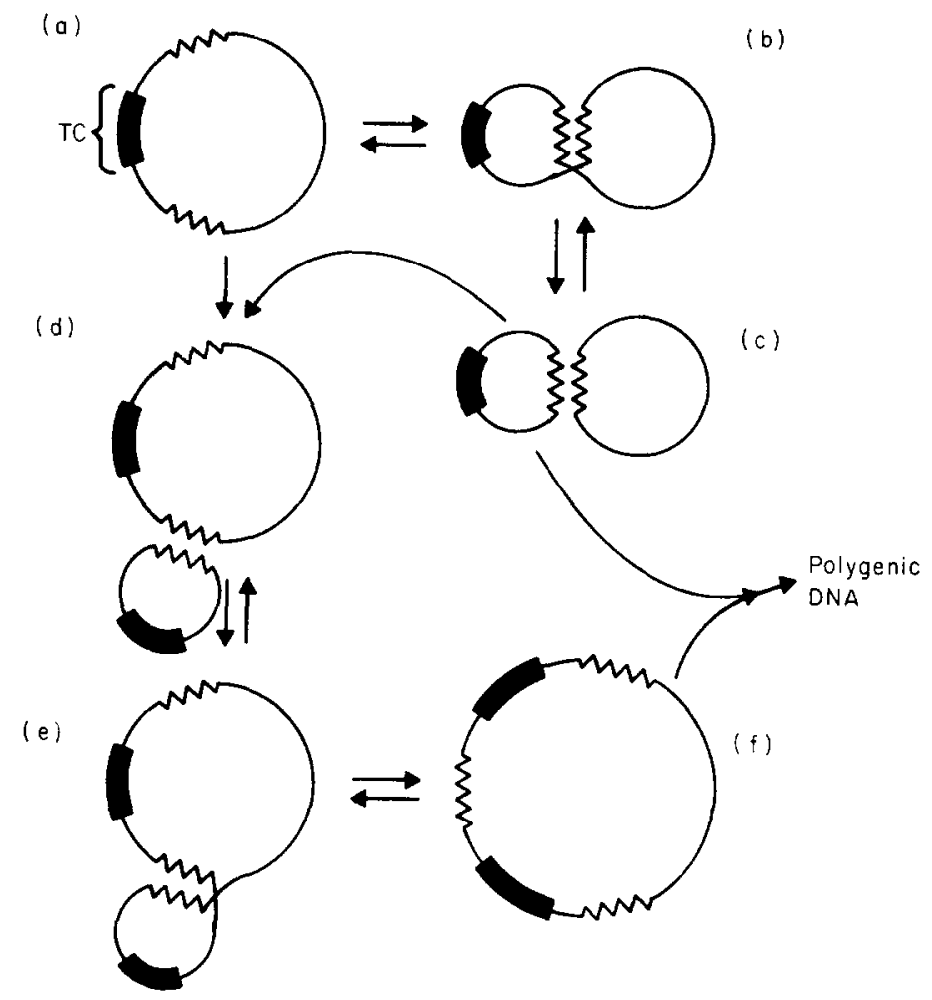

Fra. 1. A model (Model I) for the generation of plasmid DNA molemilas with a. deletion or with repests of the tetracycline (TC) resistance determinant. In (a), pAM $\alpha 1$ is shown with the heavily darkened region representing the tetracycline determinant and the 2 zig-zag regions representing regions homologous with each other; (b) to (f) represent steps by which both the deletion and duplication of the tetracycline gene can occur by recombinational processes involving the 2 regions of homology. As shown, a repetition of this recombinational process could lead to a larger number of repeated segments. 
subsequently cultured in the absence of tetracycline for a number of generations, there was a return to the original state. It was proposed that the increase in size involved the generation of tandem repeats of a 2.8 megadalton segment (containing the tetracycline resistance determinant) and two models were offered with regard to the possible mechanism by which the amplification process might occur. An important feature of both models is a recombination event between two homologous sequences with approximately a $2 \cdot 8$ megadalton spacing. That such sequences are likely to exist was supported by the observation that tetracycline-sensitive variants of DS-5Cl always have a $2 \cdot 8$ megadalton deletion in pAM $\alpha 1$, presumably generated by an internal recombination event. The two models are shown in Figures 1 and 2 . Model 1 (Fig. 1) involves the "looping out" of the 2.8 megadalton segment containing the tetracycline determinant followed by its integration into an intact pAM $\alpha \mathrm{l}$

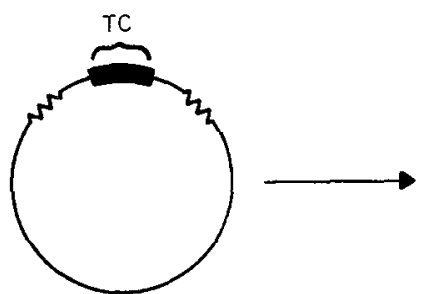

(a)

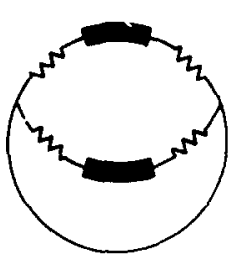

(b)

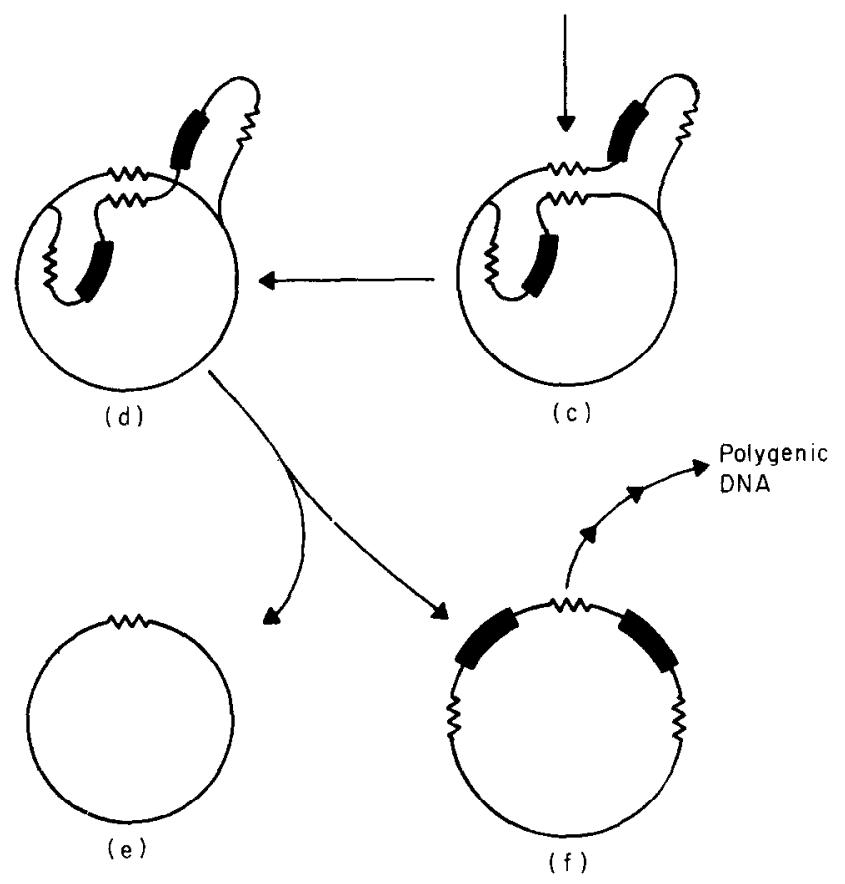

Fic. 2. A model (Model II) for the generation of plasmid DNA molecules with a deletion or with repeats of the tetracycline resistance determinant. For the molecule shown in (a), the designations are the same as described for Model I (Fig. l(a)). A partially replicated molecule is shown in (b). An uneven recombinational event between the 2 homolagous regions (c) to (f) ultimately results in the generation of 2 daughter molecules - one of which has a deletion whereas the other has a gene duplication. Polygenic DNA could be generated by repeats of this process. TC, tetracyoline site. 
plasmid. (There are about ten copies of pAM $\alpha$ l plasmid per chromosomal genome equivalent (Clewell et al., 1974). The second model (Fig. 2) involves an uneven recombinational event between the nascent daughter strands of a partially replicated plasmid. It was proposed that the recombination events (regardless of which mechanism may be operating) occur under "normal" (non-selective) growth conditions at a low frequency (probably on the order of $10^{-2}$ to $10^{-3}$ per generation) and that the resulting recombinant forms are selected for under "abnormal" conditions such as in the case when tetracycline is present in the medium.

A difficulty in doing detailed studies on the amplification phenomenon in strain DS-5Cl stems in part from the presence of $p A M \gamma 1$. The latter plasmid interferes with sedimentation analyses as well as studies involving electron microscopy and restriction endonucleases. An additional problem relating to correlation of the level of drug resistance to plasmid behavior stems from the very high basal level of tetracycline resistance in the DS-5Cl host. These problems have recently been overcome in that it is now possible to construct strains which harbor only $\mathrm{pAM} \alpha \mathbf{l}$ and which have levels of tetracycline resistance that are more easily dealt with (i.e. well below the saturation point of tetracycline in the medium). This has been done by taking advantage of the fertility properties of pAM $\gamma 1$. Using a plasmid-free isolate of S. faecalis strain JH2-2 (Jacob \& Hobbs, 1974) as a recipient in a mating experiment using strain DS-5 as a donor, exconjugants have been obtained which carry both $\mathrm{pAM} \alpha 1$ and $\mathrm{pAM} \gamma 1$, or each one separately (Dunny \& Clewell, 1975). Strain DT-11 is an exconjugant that harbors only pAM $\alpha$ l. Using this strain we have now carried out detailed molecular studies on the amplification phenomenon and report here evidence that provides strong support for the fact that the "enlarged" structures of pAM $\alpha 1$ contain tandem repeats of a 2.65 megadalton segment of DNA. The "unit of amplification" is also shown to correspond in size to that amount of DNA which is deleted in the generation of a tetracycline-sensitive variant.

\section{Materials and Methods}

(a) Materials

Most of the materials and sources were as previously described (Clewell et al., 1974,1975). EcoRI was from Miles laboratory; $\Lambda$ garoso was obtained from ScaKem; yeast extract was from Difco.

\section{(b) Bacteria and media}

S. faecalis strain DT.11 was constructed in a manner described in detail elsewhere (Dunny \& Clewell, 1975). Essentially it represents a tetracycline resistant exconjugant from a mating between the plasmid-free tetracycline sensitive strain $\mathrm{JH} 2-2$ and strain DS-5 (a strain harboring pAM $\propto 1, \mathrm{pAM} \beta 1$, and $\mathrm{pAM}_{\gamma 1}$ ) (see Clewell et al., 1974). Strain DT-11 harbors only the plasmid pAM $\alpha$ l.

The liquid broth used for routine cultivation and labeling of cells was an M9-glucose medium (Clowes \& Hayes, 1968) supplemented with $0.3 \%$ yeast extract and $0.5 \%$ Casamino acids (abbreviated here as M9.YE). For making agar plates Difco Penassay broth (antibiotic medium no. 3; (designated here as AB3)) was utilized. Cell growth was at $37^{\circ} \mathrm{C}$ with aeration. Turbidity was monitored by measuring Klett units in a Klett-Summerson colorimeter with a no. 54 filter.

\section{(c) Isolation of tetracycline sensitive variants}

The procedures concerning the isolation of tetracycline sensitive derivatives of strain DT-11 were, for the most part, similar to that previously described for the case of strain 
DS.5CI (Clewell et al., 1975). Tetracycline sensitive variants, such as DT-11C1, represented colonies that grew on a tetracycline-free AB3 agar plate but failed to grow on an AB3 agar plate containing $10 \mu \mathrm{g}$ tetracycline $/ \mathrm{ml}$.

\section{(d) Preparation of lysates}

Sarkosyl lysates were prepared using a procedure that has been described in detail previously (Clewell et al., 1974). The method essentially consisted of treating cells with $\mathrm{Na}_{2}$ ethylenediaminetetraacetic acid (EDTA)-lysozyme and then Pronase, followed by lysis with Sarkosyl.

\section{(e) Centrifugation procedures}

Preparative dye-buoyant density equilibrium as well as sucrose density-gradient centrifugation, fractionation of gradients, and the counting of radioisotopes were as described elsewhere (Clewell, 1972; Clewell \& Helinski, 1970). In some cases when a large quantity of DNA was required, dye-buoyant density centrifugation was performed utilizing a Beckman 60Ti rotor in place of the more routinely used 50Ti rotor. In that case $24 \mathrm{ml}$ of DNA sample in TES $(0.03 \mathrm{~m}$-Tris, $0.005 \mathrm{~m}-\mathrm{EDTA}, 0.05 \mathrm{~m}-\mathrm{NaCl}, \mathrm{pH} 8.0)$ containing $4.5 \mathrm{mg}$ of the intercalating dye ethidium-bromide was mixed with $22.5 \mathrm{~g}$ of $\mathrm{CsCl}$.

\section{(f) Treatment of plasmid DNA with EcoRI and analysis by agarose gel electrophoresis}

For these experiments plasmid DNA was concentrated by an ethanol precipitation method. $6.0 \mathrm{ml}$ of dialyzed plasmid DNA (dialyzed against $0.0015 \mathrm{~m}$-sodium citrate, $0.015 \mathrm{M}-\mathrm{NaCl}, \mathrm{pH} 7.5$ ) was mixed with $12.0 \mathrm{ml}$ of absolute ethanol and $0.6 \mathrm{ml}$ of $3.0 \mathrm{M}$ sodium acetate ( $\mathrm{pH} 6 \cdot 8$ ). This mixture was divided into 4 parts, each of which was kept in a polyallomer centrifuge tube (size 2.0 in $\times 0.5$ in) and stored at $-20^{\circ} \mathrm{C}$ overnight. The DNA was then pelleted by centrifugation in a Beckman SW50.1 rotor at 25,000 revs/min for $30 \mathrm{~min}\left(4^{\circ} \mathrm{C}\right)$. The pelleted DNA was dissolved in $25 \mu 1$ of buffer consisting of $50 \mathrm{mM}-\mathrm{NaCl}, 10 \mathrm{~mm}-\mathrm{MgCl}_{2}$ and $50 \mathrm{~mm}$-Tris ( $\left.\mathrm{pH} 7 \cdot 5\right)$.

The EcoRI endonuclease digestion was carried out as follows: $1.0 \mu \mathrm{g}$ of plasmid DNA was mixed with $1.0 \mu$ l of 2 -fold-diluted EcoRI (Miles: Escherichia coli Restriction Endonuclease $\mathrm{RI}, 1 \cdot 0 \pm 0 \cdot 4 \times 10^{3}$ units $/ \mathrm{ml}$, control no. 31-3-700). (Final volume of mixture was less than $15 \mu \mathrm{l}$.) The rnixture was incubated at $37^{\circ} \mathrm{C}$ for $1 \mathrm{~h}$ after which the reaction was stopped by adding $1.0 \mu \mathrm{l}$ of EDTA $(0.25 \mathrm{M}, \mathrm{pH} 7 \cdot 4)$. Controls consisting of untreated plasmid DNA were carried out in parallel with all conditions identical except that EcoRI was absont. Tho sample was thon hoated to $65^{\circ} \mathrm{C}$ for $5 \mathrm{~min}$ and immodiately cooled on ico. Agarose gel electrophoresis was similar to that described by Helling et al. (1974). After adding an equal volume of sucrose-bromophenol blue solutions ( $75 \%$ sucrose, $0.0375 \%$ bromophenol blue) in TEA + $\mathrm{NaCl}$ (40 mM-Tris, $20 \mathrm{mM}$-sodium acetate, 2 mM-EDTA, $18 \mathrm{mM}-\mathrm{NaCl}, \mathrm{pH} 8 \cdot 0$ ) to the reaction mixture, the sample was layered onto $0.7 \%$ agarose gels in glass tubes (dimension of gels was $0.6 \mathrm{~cm} \times 15.0 \mathrm{~cm}$ ). The sample was electrophoresed into the gel for $5 \mathrm{~min}$ at $100 \mathrm{~V}$ and then at $22.5 \mathrm{~V}$ for $18 \mathrm{~h}$ (or until the tracing dye ran off the gel). The buffer system was TEA $+\mathrm{NaCl}$ and the temperature was $25^{\circ} \mathrm{C}$. The gels were stained with a solution of ethidium bromide $(1 \mu \mathrm{g} / \mathrm{ml})$ for $30 \mathrm{~min}$ and then visualized on a C50 Transilluminator (Ultraviolet Products, San Gabriel, Calif.). The gels were photographed using a yellow filter (Kodak no. 9 Wratten gelatin filter) and Polaroid type $55 \mathrm{P} / \mathrm{N}$ film. In certain cases the negatives were traced using a Joyce-Loebl microdensitometer in order to quantitate the relative densities of the DNA bands.

Molecular weight estimates of the EcoRI-generated fragments were based on the migration rate relative to EcoRI-generated fragments of lambda DNA (obtained from H. Whitfield) of known molecular weights (see Helling et al., 1974).

\section{(g) Electron microscopy}

The electron microscopic technique used here was for the most part as previously described (Clewell et al., 1974). The heteroduplex experiments were performed as described by Sharp et al. (1972). In the latter experiments nicking of the molecules was carried out by heating the DNA to $95^{\circ} \mathrm{C}$ for $20 \mathrm{~min}$. 


\section{Results}

(a) Characterization of tetracycline-sensitive variants of $\mathrm{S}$. faecalis strain DT-11

It was reported previously in the case of strain DS-5Cl that tetracycline-sensitive variants containing a deletion in pAM $\alpha 1$ could be derived by incubating cells at $45^{\circ} \mathrm{C}$ for 2 to 3 weeks (Clewell et al., 1975). Under such conditions 1 to $80 \%$ of the survivors were tetracycline-sensitive. Similar results were obtained by incubating strain DT-11 at $45^{\circ} \mathrm{C}$, although we soon found that drug-sensitive variants appear spontaneously under normal conditions (i.e. during cultivation at $37^{\circ} \mathrm{C}$ in $\mathrm{M9}$-YE broth) at a frequency of about one per cent. (Spontaneously appearing tetracyclinesensitive variants of strain DS-5Cl have not been observed at the $0 \cdot 1 \%$ level or greater.) The m.i.c. $\dagger$ of tetracycline for the variants was $1 \mu \mathrm{g} / \mathrm{ml}$ in M9-YE broth (as compared to $25 \mu \mathrm{g} / \mathrm{ml}$ for the parent), which is considerably lower than is the case of variants of the original host strain DS-5C1. The m.i.c. for the latter strain is $250 \mu \mathrm{g} / \mathrm{ml}$, while its tetracycline-sensitive variants have an m.i.c. of $60 \mu \mathrm{g} / \mathrm{ml}$. Thus the level of tetracycline resistance can vary dramatically, depending on the particular bacterial host. Tetracycline resistance was found to be expressed constitutively in strain DT-11 (data not shown), similar to the case for strain DS-5Cl (Clewell et al., 1975). Figure 3 shows a sucrose density-gradient profile of plasmid DNA from strain $\mathrm{DT}-11 \mathrm{Cl}$, a tetracycline-sensitive variant obtained by the $45^{\circ} \mathrm{C}$ incubation procedure. The covalently closed circular material is seen to sediment at $22 \mathrm{~S}$ relative

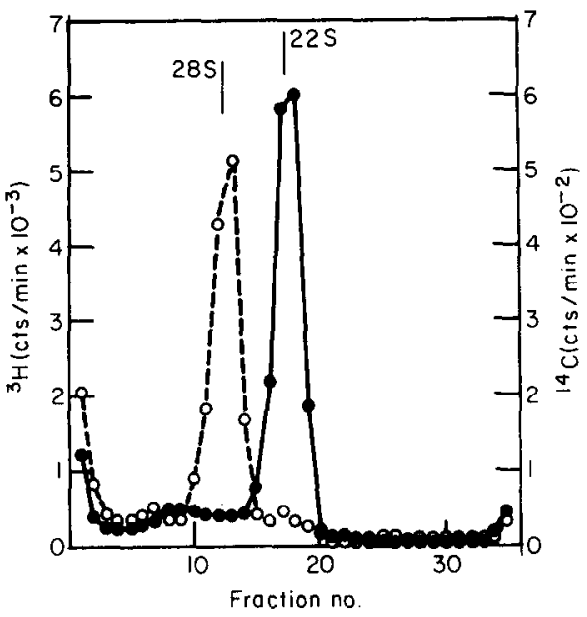

FIG. 3. Sedimentation analysis of plasmid DNA from a tetracycline-sensitive variant (DT-11Cl) of $S$. faecalis strain DT-11. A $0 \cdot 2-\mathrm{ml}$ quantity of an overnight culture of strain DT-11Cl was inoculated into M9-YE medium $(15 \mathrm{ml})$ containing $10 \mu \mathrm{Ci}\left[{ }^{3} \mathrm{H}\right]$ thymidine $/ \mathrm{ml}$, and grown for several generations in log phase. The cells were then chilled, collected by centrifugation, and mixed with a similarly grown culture of ${ }^{14} \mathrm{C}$-labeled $(6.7 \mu \mathrm{Ci} / \mathrm{ml})$ DT-11 cells. A 1 -ml sample of Sarkosyl lysate prepared from this mixture was centrifuged to equilibrium $(40,000 \mathrm{revs} / \mathrm{min}$ in a Beckman 50Ti fixed angle rotor for $60 \mathrm{~h}$ at $15^{\circ} \mathrm{C}$ ) in a $\mathrm{CsCl} /$ othidium bromide buoyant densily gradient. The gradient was fractionated and fractions containing covalently closed circular DNA were pooled, dialyzed and a $0 \cdot 2-\mathrm{ml}$ sample was sedimented through a $5 \%$ to $20 \%$ neutral sucrose densitygradient in an SW50.1 rotor $\left(15^{\circ} \mathrm{C}\right)$ at $48,000 \mathrm{revs} / \mathrm{min}$ for $115 \mathrm{~min}$.

$-0-,{ }^{3} \mathrm{H} ;-\mathrm{O}-\mathrm{O}-,{ }^{14} \mathrm{C}$.

$\dagger$ Abbreviations used: m.i.c., minimum inhibitory concentration. 
to the differentially labeled closed circular $28 \mathrm{~S}$ pAM $\alpha 1$. Similar results were obtained with two additional independently derived tetracycline-sensitive variants. Electron microscopic examination of plasmid DNA from strain DT-11C1 revealed a contour length corresponding to a molecular weight of 3.31 (stand. dev. \pm 0.09 ) million (20 molecules measured). These data are in total agreement with what has been previously observed and reported for tetracycline-sensitive variants of strain DS-5CI. Figure 4 shows heteroduplex structures consisting of a strand of $\mathrm{pAM} \alpha \mathrm{l}$ and a strand from the plasmid of strain DT-11C1. A deletion loop corresponding to the difference in size of the two molecules is clearly observed.

The plasmid alteration in tetracycline-sensitive variants of DT-Il appears to have no appreciable effect on the growth rate of the cells. Strain DT-11Cl was found to have the same doubling time $(45 \mathrm{~min})$ in drug-free broth as its DT-11 parent.

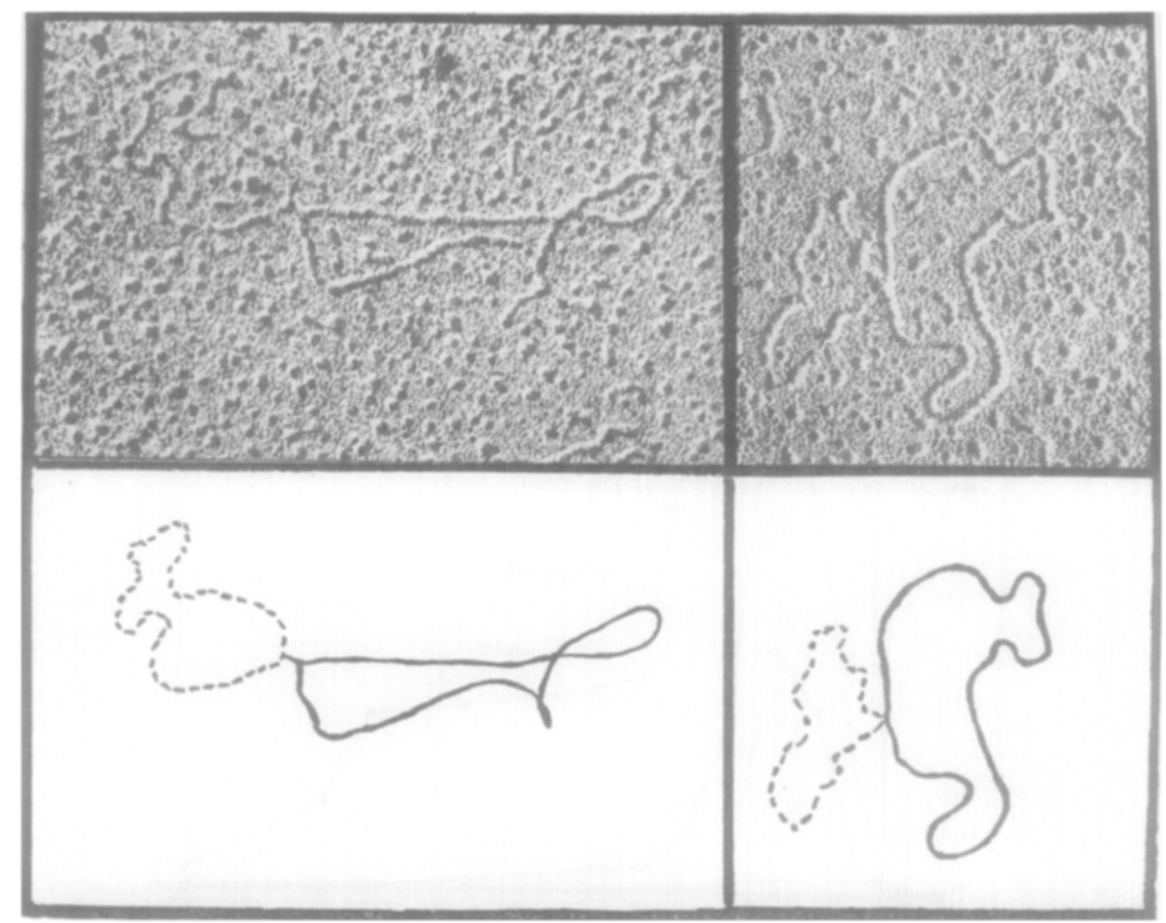

FIG. 4. Heteroduplex structures consisting of plasmid DNA from strains DT- I l and the tetracycline-sensitive variant DT-11Cl. Two heteroduplex structures are shown above along with corresponding drawings of each structure. In the drawings the solid line represents the duplexed regions, whereas the dashed line represents the single-stranded "deletion loop" of the parent pAM $\propto 1$ moleoule.

\section{(b) Growth of strain DT-11 in the presence of tetracycline}

The following experiment was carried out to determine what happens when strain DT-11 is grown in the presence of drug. Initially cells from a fresh overnight culture were introduced into $100 \mathrm{ml}$ of prewarmed broth (M9-YE) containing $20 \mu \mathrm{g}$ of tetracycline per $\mathrm{ml}$. When the broth culture reached late log phase, a portion of the culture 
was serially diluted and plated on AB3 agar containing different concentrations of tetracycline. Also at this time a portion of the culture was transferred into a fresh broth medium containing tetracycline at $30 \mu \mathrm{g} / \mathrm{ml}$ and incubated similarly. Similar passages were continued successively in the broth media containing 40 and finally $50 \mu \mathrm{g}$ of tetracycline per $\mathrm{ml}$, after which a portion of the cells was transferred into and cultivated successively in drug-free broth. During the entire experiment the cells were never allowed to go into stationary phase. The results regarding the ability of the cells to grow on plates containing drug are illustrated in Figure 5. It is seen that when DT-11 cells were grown in the presence of tetracycline, the percentage of cells capable of growing on higher levels of drug increased. After a total of 53 generations in the drug-media ( 15 generations in $20 \mu \mathrm{g} / \mathrm{ml}, 11$ generations in $30 \mu \mathrm{g} / \mathrm{ml}$, 14 generations in $40 \mu \mathrm{g} / \mathrm{ml}$, and 13 generations in $50 \mu \mathrm{g} / \mathrm{ml}$ tetracycline (broth media)) there was a $100 \%$ capability of growing on 25 and $50 \mu \mathrm{g} / \mathrm{ml}$ drug plates, and approximately 50 percent on $75 \mu \mathrm{g} / \mathrm{ml}$ plates. When these cells were subsequently cultured in the absence of the drug, the level of resistance dropped. This decrease in resistance was more rapid with regard to the 50 and $75 \mu \mathrm{g}$ tetracycline per ml plates, in comparison to the $25 \mu \mathrm{g} / \mathrm{ml}$ plates. It is noted here that $25 \mu \mathrm{g} / \mathrm{ml}$ represents the m.i.c. (in broth) for this drug on cells that had not previously been exposed to drugs. Thus, in response to growth in sub-inhibitory concentrations of tetracycline the percentage of cclls capable of growing on higher concentrations of drug (both in broth and on plates) increased.

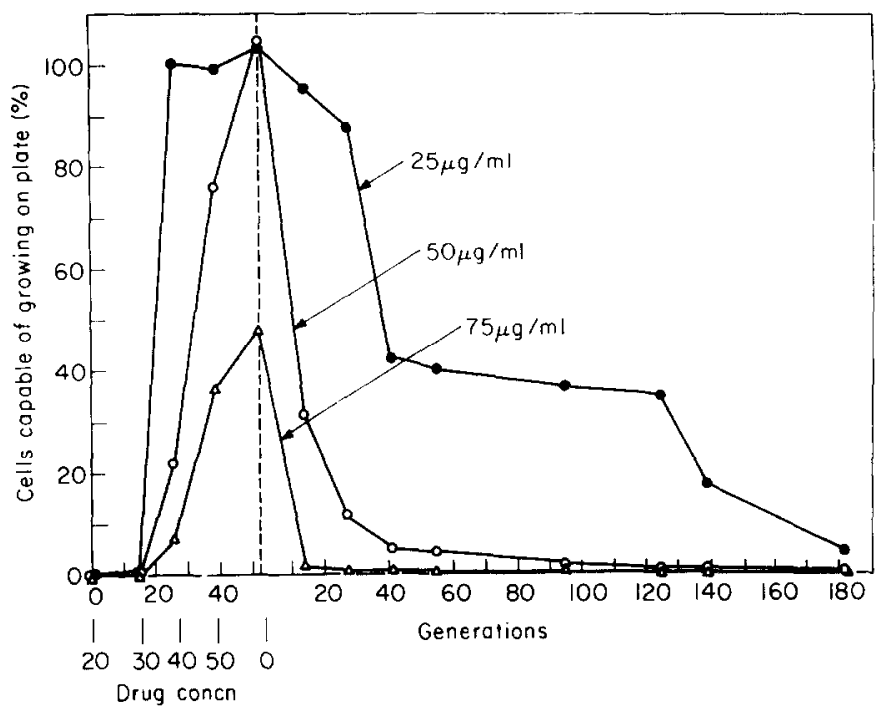

FIG. 5. Level of tetracycline resistance of strain DT-11 during growth in the presence of drug and subsequent growth in the absence of drug. Approximately $3 \times 10^{8}$ cells of a fresh overnight culture of DT-11 cells were inoculated into $100 \mathrm{ml}$ of M9.YE medium containing $20 \mu \mathrm{g}$ tetra. cycline $/ \mathrm{ml}$. When the turbidity reached approximately $85 \mathrm{Klett}$-units (log phase), $0.01 \mathrm{ml}$ of the culture was transferred into fresh broth (prewarmed) containing $30 \mu \mathrm{g}$ of $\mathrm{drug} / \mathrm{ml}$. After a similar period of cultivation transfers were made in the same manner to fresh medium containing 10 and finally $50 \mu \mathrm{g}$ of the drug per ml, after which transfers were subsequently made in drug-free broth. Immediately prior to each transfer appropriate dilutions were plated onto AB3 agar plates containing $0,25,50$ and $75 \mu \mathrm{g}$ tetracycline $/ \mathrm{ml}$ (see arrows in Fig.). The percentage of cells capable of growing on the drug plates relative to the total count on the drug-free plates was determined and plotted in each case. The estimate of the number of generations of growth was based on the growth rate and time required after each transfer to attain the final turbidity. 
During the course of the above experiment, the growth rate of the cells varied depending on the concentration of tetracycline in the medium and the length of time the cells had been growing in the presence of the drug. The doubling time when the cells were initially exposed to drug was about six hours as compared to 100 minutes during the last four generations in the highest concentration of drug used. When the drug-exposed cells were subsequently grown in the absence of drug the initial doubling time was 45 minutes, a rate similar to the doubling time of cells not previously exposed to drug. This agrees with the observation made previously regarding strain DS-5C1 (Clewell et al., 1975) indicating that there is no strong selection against cells

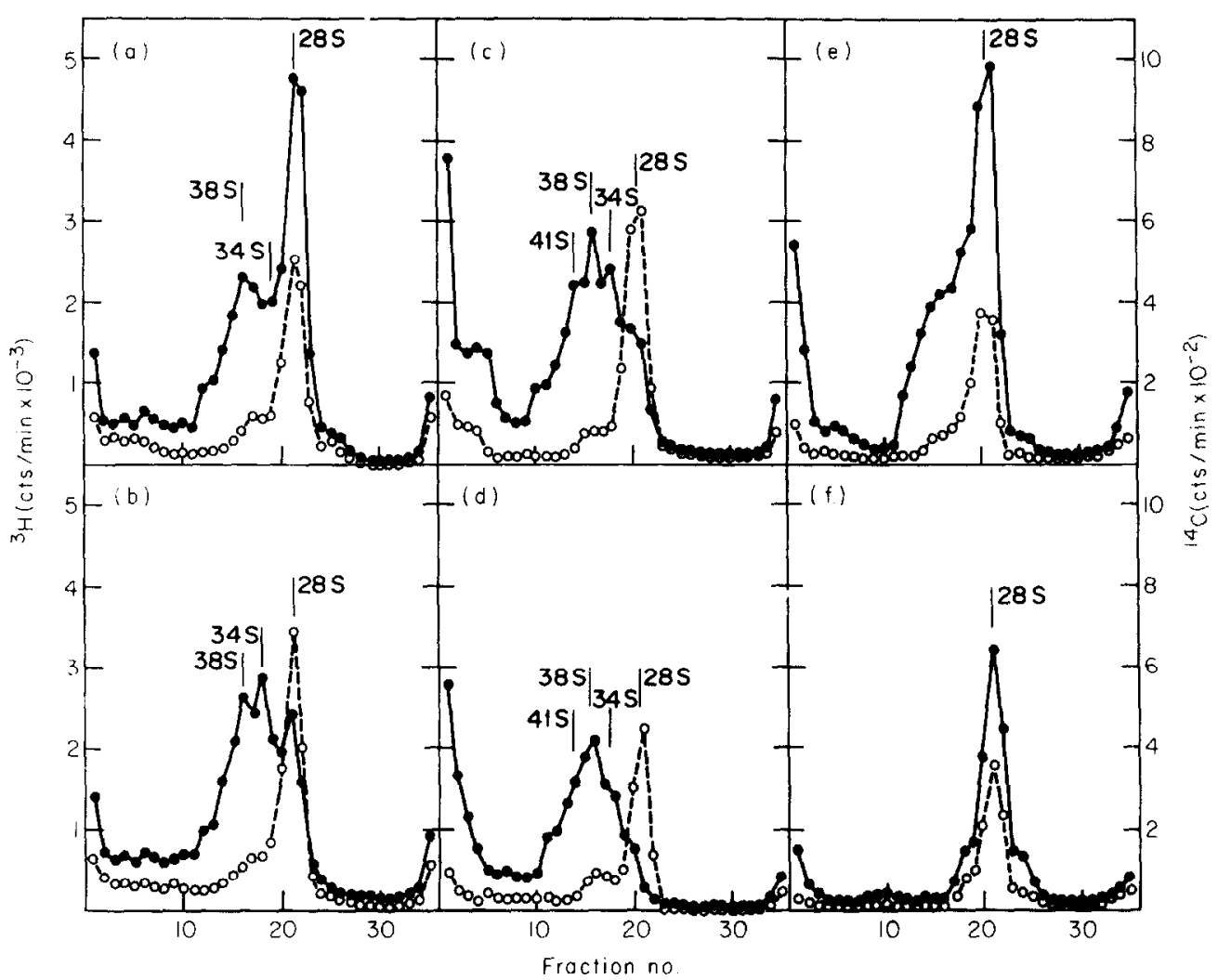

Fia. 6. Sedimentation analyses of covalently closed circular DNA molecules isolated from DT- 11 cells efter growth in the presence of tetracycline and subsequent growth in the absence of the drug. The data presented here relate to the experiment of Fig. 5. In certain cases, just. prior to the transfer of cells to fresh medium a $1-\mathrm{ml}$ portion was removed and inoculated into $15 \mathrm{ml}$ of fresh medium containing an identical concentration of tetracycline as well as $\left[{ }^{3} \mathrm{H}\right]$ thymidine $(10 \mu \mathrm{Ci} / \mathrm{ml})$. After 3 generations the cells were collected by centrifugation, mixed with cells of a parallel culture of ${ }^{14} \mathrm{C}$-labeled cells never previously exposed to tetracycline. Samples of lysates were centrifuged to equilibrium in $\mathrm{CsCl} /$ ethidium bromide buoyant density gradients and fractions containing the covalently closed circular DNA were pooled, dialyzed and sodimented through $5 \%$ to $20 \%$ neutral sucrose density-gradients $(48,000$ revs $/ \mathrm{min}$ for $60 \mathrm{~min}$ at $15^{\circ} \mathrm{C}$ ). (a) Cells after 15 generations in the presence of $20 \mu \mathrm{g}$ tetracycline $/ \mathrm{ml}$; (b) cells after 11 more generations now in $30 \mu \mathrm{g}$ tetracycline $/ \mathrm{ml}$; (c) cells after 14 more generations now in $40 \mu \mathrm{g}$ tetracycline $/ \mathrm{ml}$; (d) cells after 13 more generations now at $50 \mu \mathrm{g}$ tetracycline $/ \mathrm{ml}$; (e) cells after 27 generations now in the absence of tetracycline; and (f) cells after 154 more generations still in the absence of tetracycline.

$-{ }^{3} \mathrm{H} ; \cdots-\mathrm{O}-,{ }^{14} \mathrm{C}$. 
that had been grown previously in the presence of drug. We point out, however, that small differences in doubling time (e.g. 1 to 2 minutes) between drug-exposed cells and cells not previously exposed to drug would be difficult to resolve.

We next examined the sedimentation properties of pAM $\alpha \mathrm{l}$ molecules isolated from the cells that were grown in the presence and subsequently in the absence of tetracycline. During the course of the experiment of Figure 5, a portion of each culture was withdrawn just prior to each transfer, and was labeled in the presence of $\left[{ }^{3} \mathrm{H}\right]$ thymidine for approximately three generations. To serve as a control a parallel culture of DT-11 cells that had never been exposed to tetracycline was grown in the presence of $\left[{ }^{14} \mathrm{C}\right]$ thymidine. The cultures were centrifuged down, mixed, lysed together, and sedimented to equilibrium in ethidium bromide/CsCl density gradients. Plasmid DNA was isolated from the satellite peaks in ethidium bromide/CsCl density gradients and then subjected to sedimentation analyses in $5 \%$ to $20 \%$ neutral sucrose gradients giving rise to the sedimentation profiles displayed in Figure 6. After approximately 15 generations in the drug $(20 \mu \mathrm{g} / \mathrm{ml})$ there are already plasmid molecules present sedimenting faster than the normal $28 \mathrm{~S} \mathrm{pAM} \alpha 1$ molecule (Fig. 6(a)). Appearance of such heavy molecules became progressively more prominent as the cells went through more generations in tetracycline-medium (Fig. 6(b) to (d)), and this phenomenon was accompanied by a decrease in the relative amount of $28 \mathrm{~S}$ molecules. It is also observed that the heavier molecules give rise to discretc peaks sedimenting as 34, 38 and $41 \mathrm{~S}$. Using the formula of Bazaral \& Helinski (1968), these sedimentation values correspond to a series of molecules differing in size by increments of about 2.9 megadaltons.

An additional interesting point related to this experiment is the fact that the total amount of plasmid DNA relative to the bacterial chromosome remains constant (Table 1). That is, the amount of plasmid DNA does not increase to an extent that would be predicted based on the increased mass of the molecules.

\section{Table 1}

Amount of total plasmid DNA during extended growth in the presence of tetracycline

Growth condition $\uparrow$

Amount of plasmid DNA (as a fraction of chromosome DNA) divided by that value for cells not exposed to drug $\ddagger$

(a) 15 generations (gen) in $20 \mu \mathrm{g}$ tetracycline $/ \mathrm{ml}$

(b) Additional 11 gen in $30 \mu \mathrm{g}$ tetracyline $/ \mathrm{ml}$

(c) Additional 14 gen in $40 \mu \mathrm{g}$ tetracyeline/ml

(d) Additional 13 gen in $50 \mu$ g tetracycline $/ \mathrm{ml}$

(e) Additional 27 gen in the absence of tetracycline

(f) Additionel 154 gen in the absence of tetraoyoline
0.94

0.91

$1 \cdot 00$

0.90

$1 \cdot 10$

0.96

† The growth conditions (a) to (f) correspond to those described in the legend to Figure 6.

$\$$ Amount of DNA in each case was messured from radioactivity ( ${ }^{3} \mathrm{H}$ counts for celle grown in the presence of tetracycline, and ${ }^{14} \mathrm{C}$ counts for those never exposed to the drug; see the legend to Fig. 6) representing the satellite and chromosomal peaks in the CsCl/ethidium bromide buoyant density gradients. Satellite DNA corresponded to about 5 percent of the chromosomal DNA peak and ranged from 4.5 to 6.5 percent. Since the "amplified" and "unamplified" cultures (labeled with different isotopes) were lysed while mixed together, variations between the 2, due to random breakage of covalently closed circular DNA, should be minimized. 
(c) Electron microscopy of plasmid DNA from cells grown in the

$$
\text { presence of tetracycline }
$$

For this study, a DT-1I overnight culture was serially diluted and plated on AB3 plates containing $10 \mu \mathrm{g}$ of tetracycline per ml. Approximately $0.2 \%$ of the cells gave rise to colonies on these plates. We believe these to represent cells that have undergone a spontaneous amplification and have been selected for on the tetracycline plates. Further amplification would be expected as a result of selection during continued growth of the colony. After 48 hours at $37^{\circ} \mathrm{C}$ a single colony was picked and
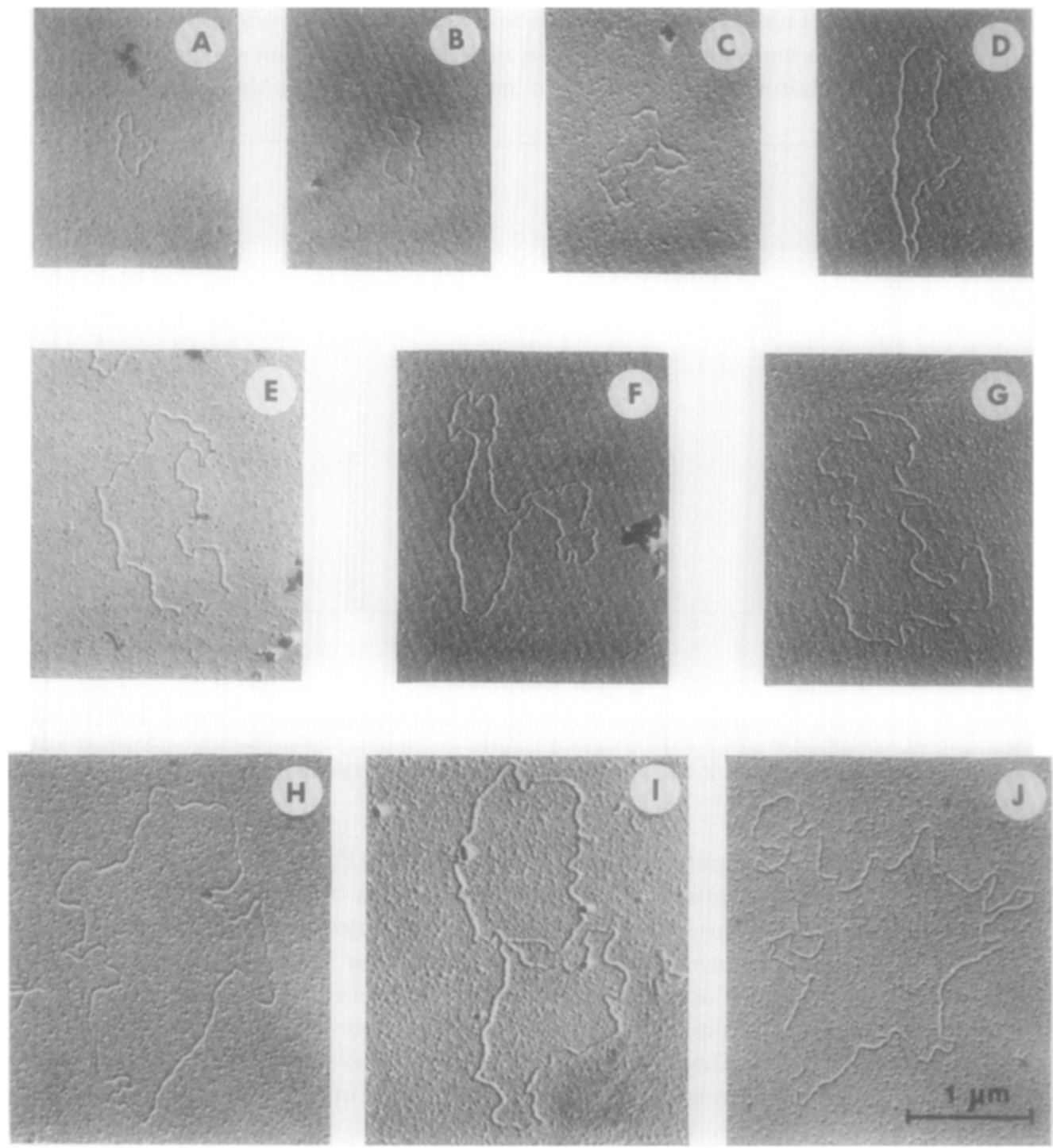

FIG. 7. Electron micrographs of circular molecules isolated from DT-11 cells grown in the presence of tetracycline. The plasmid DNA was isolated (by the CsCl/ethidium bromide method) from cells exposed to tetracycline in the manner described in the text. Representative molecules (spontaneously nicked) from a variety of different size classes are shown. The designations of the molecules (A, B, C, etc.) correspond to those designations of the histogram of Fig. 8 . 
dispersed in a tetracycline $(10 \mu \mathrm{g} / \mathrm{ml})$-broth tube $(5 \mathrm{ml})$ for overnight growth. The culture was then labeled in the presence of $\left[{ }^{3} \mathrm{H}\right]$ thymidine $(10 \mu \mathrm{Ci} / \mathrm{ml})$ and tetracycline $(10 \mu \mathrm{g} / \mathrm{ml})$ for a few generations. Plasmid DNA molecules were isolated by ethidium bromide/CsCl density gradient centrifugation and examined for their contour length. In Figures 7 and 8, molecules are shown in an order of increasing size. Figure 7(a) represents a molecule estimated to be 2.63 (stand. dev. \pm 0.07 ) megadaltons (5 molecules measured) and probably corresponds to a circular segment that has been deleted ("looped out") from pAM $\alpha$ l. Figure $7(\mathrm{~B})$ is of a size (3.56 megadalton) that would correspond to a $\mathrm{pAM} \alpha \mathrm{l}$ molecule that has had deleted from it the smaller segment of DNA. Figure 7(C) corresponds to a normal pAM $\alpha 1$, while Figure $7(\mathrm{D})$ to (J) corresponds to molecules that increase in size by discrete increments averaging about $\mathbf{2 . 6 6}$ megadaltons, with the largest molecule being of a size consistent with

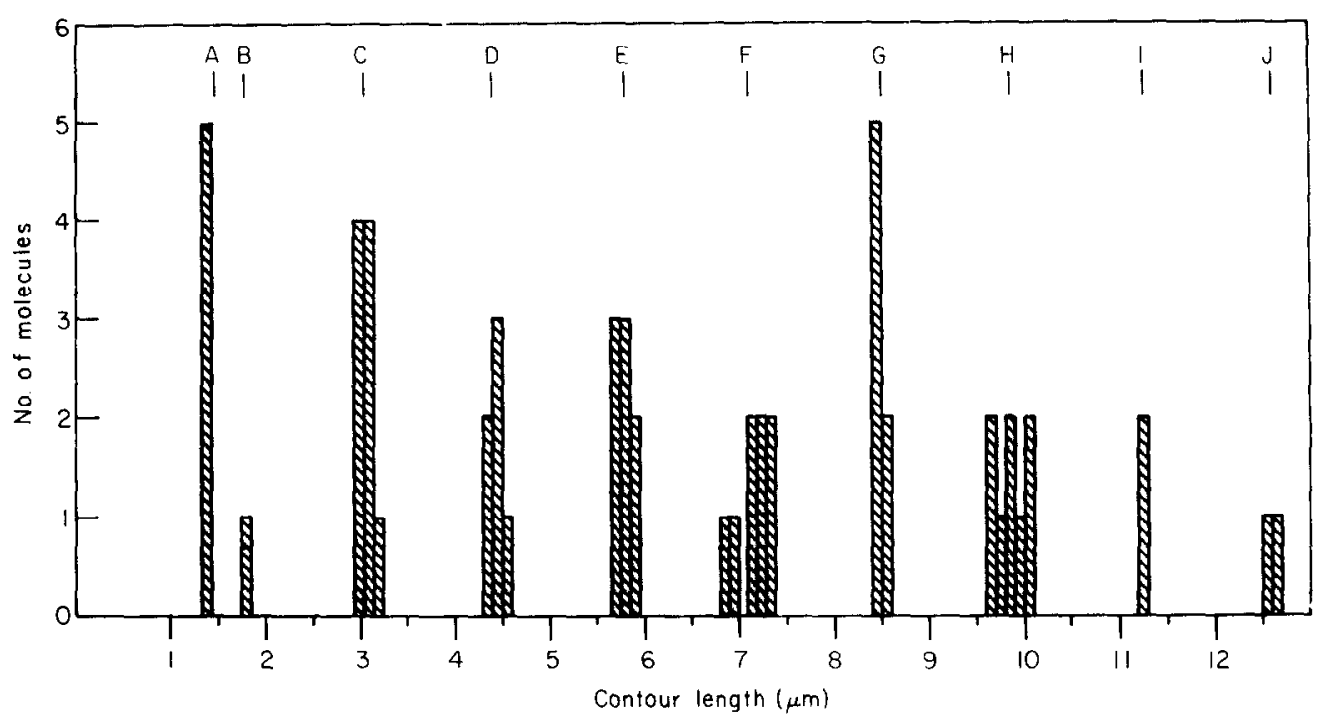

FIG. 8. Histogram of contour lengths of circular plasmid molecules isolated from DT.11 cells grown in the presence of tetracycline. Contour lengths of a number of circles were measured and found to fall into a number of size classes as depicted above. The designations (A, B, C, etc.) correspond to the representative circles shown in Fig. 7.

having seven additional units of the repeated segment (Fig. $7(J)$ ). Figure 9 shows a sucrose density-gradient profile of the same preparation of plasmid DNA that was analyzed by electron microscopy. In this case the molecules are generally larger than was the case in the experiment of the previous section with the majority of the material sedimenting in the range of 34 to $56 \mathrm{~S}$. We note that at these larger sizes resolution of discrete peaks would be expected to be more difficult since each increment represents a smaller percentage of the total mass. It is possible, however, to visualize roughly the relative amounts of each class of DNA in the preparation examined by electron microscopy ( 34 to $56 \mathrm{~S}$ correspond to molecules containing 1 to 8 additional segments of DNA respectively). The molecules of Figure $7(A)$ and (B) were difficult to find by microscopy, detecting only five of the former and one of the latter, out of a total of approximately 1000 molecules examined visually (direct measurements are not necessary to distinguish such small circles from the remainder of the heterogeneous population of molecules). 


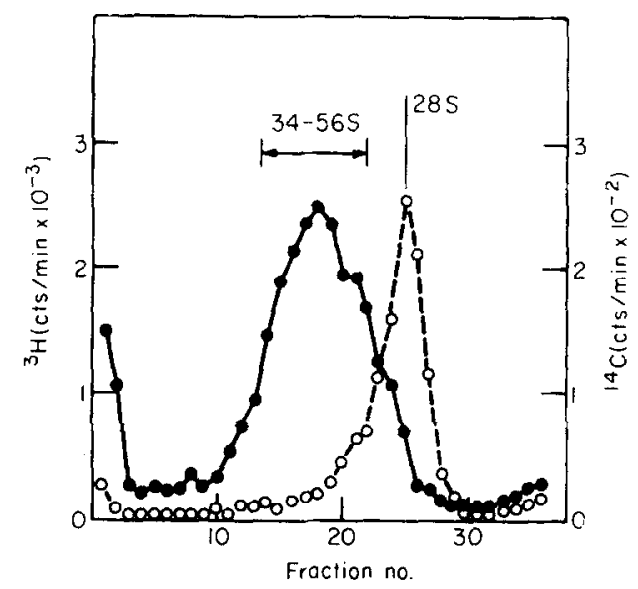

FIG, 9. Sedimentation analysis of the plasmid UNA used for the electron microscopic study of Figs 7 and 8. The plasmid DNA was sedimented through a $5 \%$ to $20 \%$ neutral sucrose density gradient using the conditions described in the legend to Fig. 6. The internal ${ }^{14} \mathrm{C}$-labeled marker DNA consisted of normal $28 \mathrm{~S}$ pAM $\propto 1$ DNA.

$-\mathrm{O}-{ }^{\mathrm{a}} \mathrm{H} ;-\mathrm{O}-\mathrm{O}-\mathrm{-},{ }^{14} \mathrm{C}$.

\section{(d) EcoRI digestion of the various forms of $p A M \alpha I$}

The following forms of $\mathrm{pAM} \alpha \mathrm{l}$ were prepared and digested with the $E$. coli restriction endonuclease EcoRI: $p A M \alpha 1$ (abbreviated $\alpha$ ), pAM $\alpha$ l with the tetracycline resistance gene deleted (abbreviated $\alpha \mathrm{d}$ ), and amplified (modified plasmid, abbreviated $\mathrm{M} \alpha$ ). The resulting fragments were then analyzed by agarose gel electrophoresis, the results of which are shown in Figure 10. Figure $10(a)$ and (b) represents, respectively, treated and untreated samples of $\alpha \mathrm{d}$. In both cases the patterns look identical. The two bands observed correspond to supercoiled and nicked circular forms of the plasmid (the former migrating more rapidly). Thus there is no sequence in the molecule recognized by the endonuclease. However, in the case of $\alpha$ (Fig. 10(c) and (d)) two major new fragments are seen to appear after exposure to the nuclease indicating the introduction of two breaks. These fragments are designated $\alpha_{1}$ and $\alpha_{2}$; and based on their migration rates relative to EcoRI-generated marker fragments of bacteriophage lambda DNA, their molecular weights are 4.2 and 1.75 million, respectively (Fig. $10(\mathrm{~g})$ ). These two values add up to 5.95 million which is very close to the previously estimated molecular weight of $\mathrm{pAM} \alpha \mathbf{l}$ determined by electron microscopy (i.e. 6.0 million); thus there must be one copy of $\alpha_{1}$ per copy of $\alpha_{2}$ (a conclusion which can also be drawn based on the relative densities of the two bands which differ due to their difference in mass). When untreated $\mathbf{M} \alpha$ was analyzed by electrophoresis (Fig. 10(e)) it was difficult to resolve any distinct bands. We attribute this to the heterogeneity of the DNA that exists in this preparation. When the same material, however, was treated with EcoRI three fragments were generated (Fig. 10(f)), two of which correspond to $\alpha_{1}$ and $\alpha_{2}$. A third fragment designated $\alpha_{3}$ has a molecular weight estimated to be 0.9 million. In Figure 11 are presented densitometer tracings of the fragment patterns of both $\alpha$ and $M \alpha$ (i.e. of the gels seen in Fig. I0(d) and (f)), where it is seen that the relative amounts of $\alpha_{1}$ and $\alpha_{2}$ differ in the two cases. The amount of $\alpha_{2}$ relative to $\alpha_{1}$ in the case of the amplified DNA (M $\left.\alpha\right)$ is much higher 


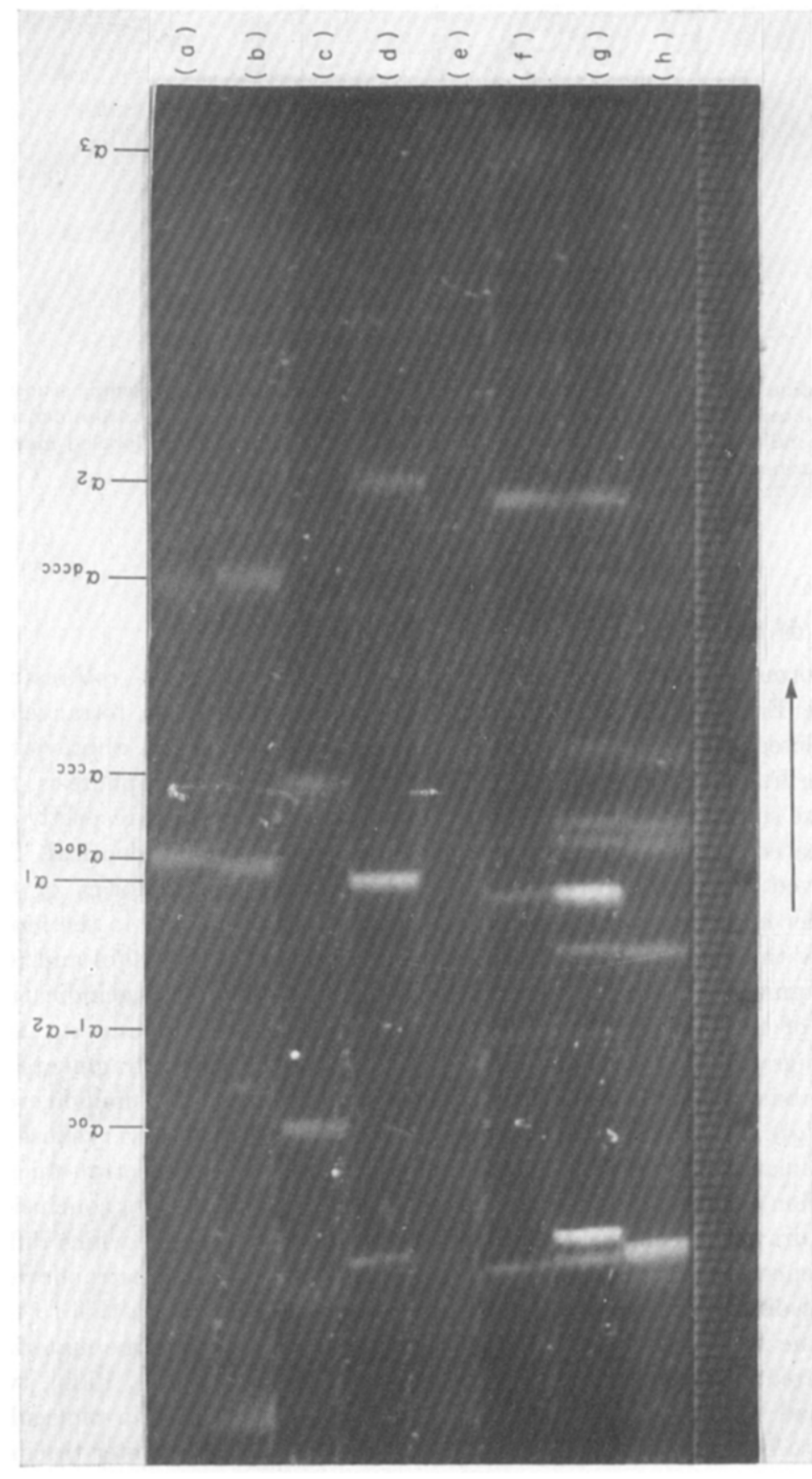

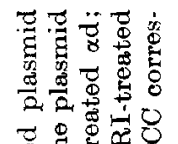

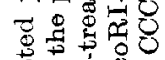

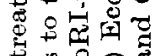

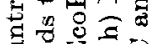

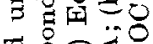

范要还员

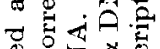

远品

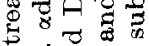

它官范

잉

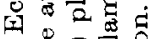

म

象乐

政

$\exists$ 요요

. 대웡

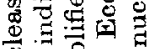

设

$5=\pi$

명

귱

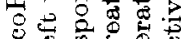

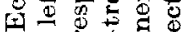

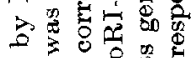

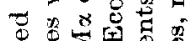

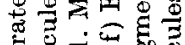

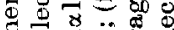

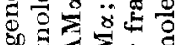
- 正运

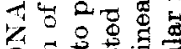

A 5 is 월

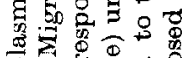
क 4. 요의 둥 등

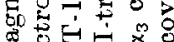

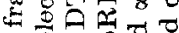
4 형 它 की th द 0 वे 앙 30 \%

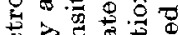
800

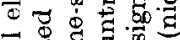

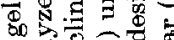

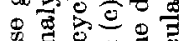

कू

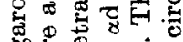
so $\$ \tau \dot{4}$

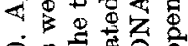
0 品A 궁 过总造焉

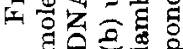



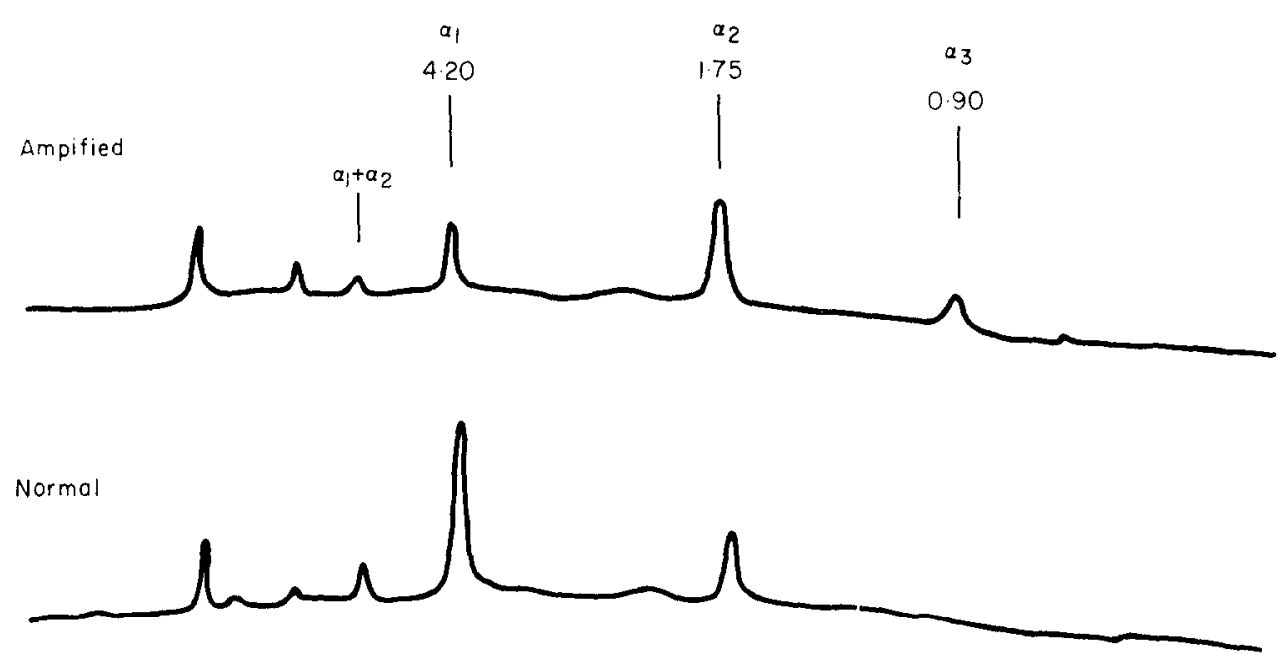

Migration

FIG. 11. Densitometer tracing of the DNA bending patterns shown in Fig. 7(C) and (F). These correspond to the fragments generated by EcoRI digestion of $\approx$ (normal) and $\mathrm{M}_{\alpha}$ (amplified), respectively.

than is the case for the normal-sized plasmid. By dividing the relative areas defined by each peak by the respective molecular weights, we have computed that on the average there must be five $\alpha_{2}$ fragments and four $\alpha_{3}$ fragments for every $\alpha_{1}$ fragment.

An interpretation of these data is visualized in Figure 12. Since the ad molecule is insensitive to the endonuclease, the two breaks on $\alpha$ must occur on that segment of DNA which is missing in $\alpha \mathrm{d}$-perhaps on either side of the tetracycline determinant. On this basis $M \alpha$ DNA must consist of tandem repeats with the segment corresponding to $\alpha_{3}$ acting as a connecting piece for segments corresponding to $\alpha_{2}$. (Because the $\alpha_{1}$ fragment is preserved intact in the amplified structure, the repeated sequences must be arranged in tandem.) It is noted that in such an amplified structure (Fig. 12) the number of enzyme-generated $\alpha_{3}$ fragments would be one less than the number of $\alpha_{2}$ fragments (agreeing with the observed data). The presence of the homologous segment on the $\alpha_{3}$ fragment is based on the models which have been offered (Figs 1 and 2) to explain how such amplified structures are generated. The size of the unit of repetition in the amplified molecules corresponds to the sum of the $\alpha_{2}$ and $\alpha_{3}$ fragments, or 2.65 million. It is noteworthy that this value corresponds to the difference in size between $\alpha$ and $\alpha d$.

With regard to the agarose gel banding patterns shown in Figure 10 we note that there are a few additional bands of heavier molecular weight in the case of the enzymetroated $\propto$ and $M \propto$ preparation. One of these is probably a lincar molcculc consisting of $\alpha$ with only one break (incompletely digested DNA). The other(s) is probably a fragment of chromosomal DNA which we know to be present to some extent in the preparation due to incomplete separation of plasmid from chromosomal DNA in the ethidium bromide/CsCl gradients. 

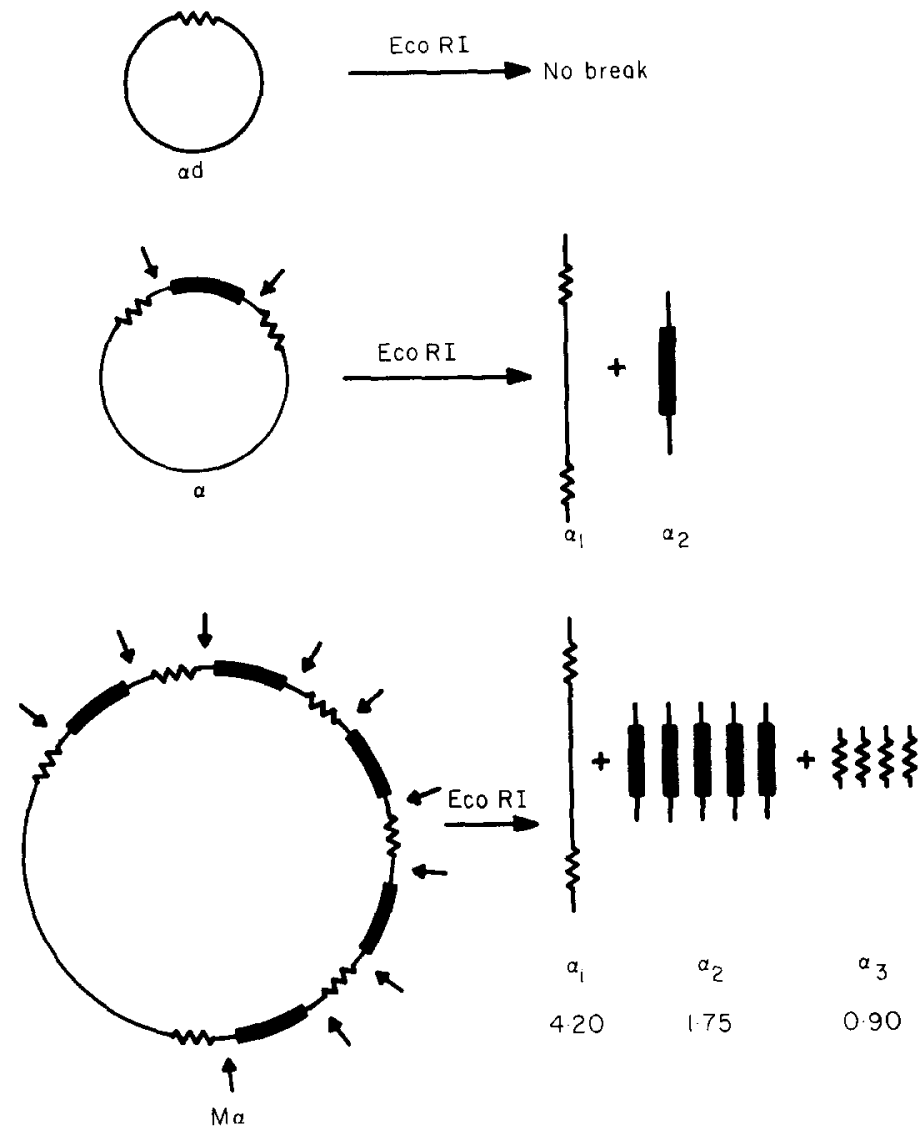

Fia. 12. An interpretation of the structures of the various forms of pAM $\alpha 1$ with regard to the relative location of the EcoRI cleavage sites (indicated by the arrows). The molecular masses of the $\alpha_{1}, \alpha_{2}$ and $\alpha_{3}$ fragments are designated (in megadaltons).

\section{Discussion}

Several observations have been reported here which bear significantly on our visualization of the amplified forms of $\mathrm{pAM} \alpha \mathrm{l}$ and the mechanism(s) by which such forms may be generated. First, it was found that tetracycline-sensitive variants of strain DT-11 have plasmid DNA of a smaller size than the parent strain, and heteroduplex studies proved this to be due to a deletion of a single segment of DNA. Second, the growth of strain DT-11 in the presence of tetracycline resulted in a gradual "enlargement" of pAM $\alpha \mathrm{l}$ which could be correlated with an increased level of resistance to drug; and this phenomenon was reversible. Third, it was shown convincingly by analyses of the various forms of pAM $\alpha 1$ (normal, deleted and amplified) by sedimentation, electron microscopy and treatment with the restriction endonuclease EcoRI that the "enlargement" of pAM $\alpha$ l consists of units of repetition corresponding to about $2 \cdot 65$ megadaltons of DNA, a value which corresponds to the amount of DNA deleted from $\mathrm{pAM} \alpha \mathrm{l}$ in the generation of a tetracycline-sensitive variant. And last, the endonuclease data provided, in addition, evidence that the repeated sequences in the amplified molecules are arranged tandemly.

While the evidence supports both of our models for amplification there is no hard 
evidence yet that would favor one of the models over the other. As we have previously indicated (Clewell et al., 1975) it is possible that both mechanisms are operating. Regarding Model I (Fig. I) it is conceivable that once the 2.65 megadalton piece containing the tetracycline determinant has "looped out" to become a small circle it could possibly replicate independently and generate oligomers similar to the situation proposed by Rownd and collaborators for the NR1 plasmid system in Proteus mirabilis (Rownd et al., 1975). However, the results of our electron microscopic analyses indicated that the vast majority of the molecules in cells grown in drug represented structures which corresponded to a basic pAM $\alpha$ l with additional 2.65 megadalton segments of DNA. A few 2.65 megadalton circles were observed in a DNA preparation from cells grown in tetracycline (e.g. see Fig. 7(a)), but these could represent monomer units that had been deleted from the larger structures. In addition the sedimentation analyses of plasmid DNA from cells in the various stages of amplification provided no evidence for any covalently closed circular DNA corresponding to monomers or dimers of the 2.65 megadalton piece (see Fig. 6). We estimate that such structures would sediment at about $19 \mathrm{~S}$ and $26 \mathrm{~S}$, respectively. It is conceivable, however, that such structures might not be present as covalently closed circular molecules and would therefore have not been recovered by the isolation techniques used here. We favor the notion, however, that the 2.65 megadalton circles are probably incupable of replicating autonomously; or if they do in fact replicate, it is with a low efficiency.

Models similar to our Model I have been suggested recently from other laboratories, in relation to certain R-plasmids found in gram negative bacteria (Rownd et al., 1975; Ptashne \& Cohen, 1975; Hu et al., 1975). In some cases these proposed models were based on the detection by heteroduplexing techniques of repeated sequences consisting of known insertion (or IS) sequences at the two sites where a segment of DNA containing resistance-determinants are joined to form a cointegrate (composite) structure with a larger plasmid known as the RTF (resistance transfer factor) (Ptashne \& Cohen, 1975; Hu et al., 1975). Such sequences are analogous to those proposed to exist in pAM $\alpha 1$ on either side of the tetracycline resistance determinant. We will subsequently refer to these sequences as RS sequences (designating recombination sequence). We are currently carrying out heteroduplexing experiments in an attempt to demonstrate directly the existence of such RS sequences. If they are in fact present in the $\alpha_{3}$ fragment generated from the EcoRI endonuclease treatment of amplified molecules (see Fig. 12), it should be possible to anneal the RS portion of such fragments at two places on a normal-sized denatured $\mathrm{pAM} \alpha \mathrm{l}$ molecule and at one place on the smaller plasmid of a tetracycline-sensitive variant. Preliminary evidence already indicates that this is in fact the case and that the RS sequences in $\mathrm{pAM} \alpha \mathrm{l}$ are direct repeats.

Because of the remarkably close proximity of the EcoRI cleavage to the putative RS sequences of pAM $\alpha$ l (see Fig. 12) it is tempting to speculate on a possible relationship between the two. However, on the basis of our two models the nuclease cleavage probably does not occur within the RS sequence itself, since molecules with a deletion of the tetracycline determinant (presumed to still have one RS sequence) are insensitive to the enzyme.

Regarding the overall maintenance of $\mathrm{pAM} \alpha \mathrm{l}$, it is interesting that when plasmid DNA is in an amplified state the total amount of plasmid DNA relative to chromosomal DNA was found to be similar to that of unamplified DNA (see Table 1). Such 
an observation, indicating that when the molecules are larger there are fewer of them, suggests that despite the fact that there are a number of plasmid molecules per chromosome (about 10 when in the unamplified state) the number of replication sites in the cell is limited to only one or a few. Thus, the initiation of a round of plasmid DNA synthesis would be dependent on the prior completion of a previous round of replication. Since replication of the larger molecules would occupy a larger fraction of the division cycle, initiation of new rounds would be less frequent.

This work was supported by U.S. Public Health research grants no. AI10318 (National Institute of Allergy and Infectious Diseases) and no. DE02731 (National Institute of Dental Research), One of the authors (D.B.C.) is the recipient of a Research Career Development Award, K04 AI00061 (National Institute of Allergy and Infectious Diseases). We gratefully acknowledge Drs H. Whitfield, W. Folk and R. Helling for help in learning the techniques involved in the EcoRI endonuclease analyses, and Drs $H$. Whitfield and W. Folk for gifts of phage lambda DNA.

\section{REFERENCES}

Bazaral, M. \& Helinski, D. R. (1968). Biochemistry, 7, 3513-3520.

Clewell, D. B. (1972). J. Bacteriol. 110, 667-676.

Clewell, D. B. \& Franke, A. E. (1974). Antimicrob. Ag. Chemother. 5, 534-537.

Clewell, D. B. \& Helinski, D. R. (1970). Biochemistry, 9, 4428-4440.

Clewell, D. B., Yagi, Y. \& Bauer, B. (1975). Proc. Nat. Acad. Sci., U.S.A. 72, 1720-1724.

Clewell, D. B., Yagi, Y., Dunny, G. M. \& Schultz, S. K. (1974). J. Bacteriol. 117, 283-289.

Clowes, R. C. \& Hayes, W. (1968). Experiments in Microbial Genetics, Blackwell Scientific Publications, Oxford.

Dunny, G. M., Birch, N., Hascall, G. \& Clewell, D. B. (1973). J. Bacteriol. 114, 1362-1364.

Dunny, G. M. \& Clewell, D. B. (1975). J. Bacteriol. 124, 784-709.

Helling, R. B., Goodman, H. M. \& Boyer, H. W. (1974). J. Virol. 14, 1235-1244.

Hu, S., Ohtsubo, E., Davidson, N. \& Saedler, H. (1975).J. Bacteriol. 122, 764-775.

Jacob, A. E. \& Hobbs, S. J. (1974). J. Bacteriol. 117, 360-372.

Ptashne, K. \& Cohen, S. N. (1975). J. Bacteriol. 122, 776-781.

Sharp, P. A., Hsu, M., Ohtsubo, E. \& Davidson, N. (1972). J. Mol. Biol. 71, 471-497.

Rownd, R. H., Perlman, D. \& Goto, N. (1975). In Microbiology - 1974 (Schlessinger, D., ed), pp. 76-94, American Society for Microbiology, Washington, D.C.

Yagi, Y., Franke, A. E. \& Clewell, D. B. (1975). Antimicrob. Ag. Chemother. 7, 871-873. 